\title{
Potensi Daun Biduri (Calotropis gigantea) Sebagai Bahan Aktif Dye- Sensitized Solar Cell (DSSC)
}

\section{(Potential of Biduri leaf (Calotropis gigantea) as active ingredient of Dye- sensitized solar cell (DSSC))}

\author{
Suprianto $^{*}$, M. Syahrul Ulum, Iqbal. \\ Program Studi Fisika Jurusan Fisika FMIPA, Universitas Tadulako, Palu, Indonesia
}

\begin{abstract}
The research on the potential of Biduri Leaf (Calotropis gigantea) as active materials of Dye- sensitized Solar Cell (DSSC) have been conducted. Biduri leafs were extracted by meseration method using acetone 80\%. Absorbance of results extract (solution) then measured using spectrophotometry UV- Vis, and chlorophyll concentration calculated by the Arnon method. The conductivity calculated by the two-point probe method. By Microsoft Excel gained the maximum absorbance is at concentration of $0,15 \mathrm{~g} / \mathrm{ml}$ is equal to 3,352 a.u. The calculation shows that levels of chlorophyll of Biduri Leaf is $1,4621 \mathrm{mg} / \mathrm{g}$. Data from the conductivity calculation shows an increase chlorophyll solution conductivity of $0,0555(\Omega \mathrm{m})^{-1}$ at each addition concentration of $1 \mathrm{~g} / \mathrm{ml}$. Based on these data we can conclude that the Biduri Leaf has potential to be used as active materials of Dye-Sensitized Solar Cell (DSSC).
\end{abstract}

Keywords : Absorbance, Arnon Method, Conductivity, Dye-sensitized Solar Cell, Meserasi method, Spectrophotometery UV-Vis, Two-point probe.

\begin{abstract}
ABSTRAK
Penelitian tentang potensi daun biduri (Calotropis gigantea) sebagai bahan aktif Dye Sensitized Solar Cell (DSSC) telah dilakukan. Daun biduri diekstrak dengan menggunakan metode meserasi dengan pelarut aseton $80 \%$. Absorbansi hasil ektrak (larutan) kemudian diukur dengan menggunakan spektrofotometri UV-Vis, dan kadar klorofilnya dihitung dengan metode Arnon. Adapun konduktivitasnya dihitung dengan metode two point probe. Dengan menggunakan Microsoft Excel diperoleh absorbansi maksimum berada pada konsentrasi $0,15 \mathrm{~g} / \mathrm{ml}$ yaitu sebesar 3,352 a.u. Hasil perhitungan menunjukkan kadar klorofil daun biduri sebesar 1,4621 mg/g. Data hasil perhitungan konduktivitas yang diolah dengan Microsoft Excel menunjukkan kenaikan konduktivitas larutan klorofil sebesar 0,0555 $(\Omega \mathrm{m})^{-1}$ pada setiap penambahan konsentrasi $1 \mathrm{gr} / \mathrm{ml}$. Berdasarkan data-data tersebut dapat disimpulkan bahwa daun biduri memiliki potensi untuk dijadikan bahan aktif Dye-Sensitized Solar Cell (DSSC)
\end{abstract}

Kata Kunci : Absorbansi, Dye-Sensitized Solar Cell, Konduktivitas, Metode Meserasi, , Metode Arnon, Spektrofotometri UV-Vis, Two point probe. 


\section{LATAR BELAKANG}

Seiring dengan berkembangnya teknologi, dan semakin langkanya bahan bakar fosil, manusia kini mencari sumber energi alternatif. Sumber energi alternatif terbesar adalah energi surya. Total energi matahari yang sampai di permukaan bumi adalah 2,6 x 1024 Joule setiap tahunnya. Besarnya energi matahari ini membuat banyak peneliti melakukan penelitian untuk mengkonversi energi surya menjadi energi listrik. Alat konversi bekerja dengan memanfaatkan medan listrik yang dihasilkan material kontak akibat adanya penyerapan cahaya matahari. Dari berbagai alat konversi yang telah banyak diteliti salah satu yang saat ini banyak dikembangkan adalah Dye Sensitized Solar Cell (DSSC).

DSSC memiliki bahan aktif berupa zat pewarna yang menyerap energi matahari. Ketika bahan ini menyerap energi matahari, elektron- elektron dalam bahan aktif akan tereksitasi dan menghasilkan arus listrik. Bahan aktif DSSC dapat terbuat dari bahan organik dan anorganik. Dibandingakan dengan bahan anorganik, bahan organik lebih murah dan mudah diperoleh karena berasal dari tumbuh- tumbuhan. Bahan organik yang saat ini banyak digunakan adalah antosianin dan klorofil (Astuti dan Sriwulandari, 2010).
Antosianin dan klorofil merupakan zat warna yang ada dalam tumbuhan. Pada tumbuh-tumbuhan, klorofil memiliki jumlah yang lebih banyak dibandingkan dengan antosianin. Hampir semua tumbuhan tingkat tinggi memiliki klorofil dalam daun dan batangnya. Penggunaan klorofil sebagai bahan aktif DSSC telah dilakukan oleh beberapa peneliti, dan salah satunya adalah Ardianto. Dalam penelitiannya Ardianto menggunakan klorofil yang berasal dari Nannochloropsis $S p$. Jumlah klorofil yang terkandung dalam Nannocloropsis Sp berkisar 0,7820 $\mathrm{mg}$ /gram. Daya serap klorofil sebesar 4,01 Absorbance units (a.u.) pada panjang gelombang 400-500 nm dan 2,5

Absorbance Units (a.u.) pada panjang gelombang $665 \mathrm{~nm}$ untuk kosentrasi larutan $0,1 \mathrm{~g} / \mathrm{ml}$. DSSC yang dibuat dengan bahan aktif klorofil Nannoclopsis Sp. memiliki efisiensi sebesar 0,8596\% (Ardianto dkk, 2015).

Tumbuhan berklorofil yang banyak tumbuh di Indonesia pada umumnya, dan Kota Palu pada khususnya adalah tumbuhan biduri (Calotropis gigantea). Tumbuhan biduri banyak hidup di daerah yang gersang dan selama ini belum pernah dimanfaatkan, bahkan hanya dianggap sebagai rumput. Selain itu daun biduri dilapisi oleh zat lilin (Witono, 2008). Zat lilin berfungsi untuk 
mengurangi respirasi dan menahan intensitas cahaya matahari yang masuk ke dalam daun. Hal memungkinkan klorofil pada daun biduri memiliki daya serap yang tinggi terhadap sinar matahari (Adisti, 2007).

\section{BAHAN DAN METODE}

Bahan yang digunakan dalam penelitian ini adalah Daun biduri sebagai bahan dasar dan Aseton 80\%. Tahapan dalam melakukan penelitian adalah sebagai berikut.

\section{Ekstraksi larutan.}

Ektraksi dilakukan dengan Metode Meserasi yaitu dengan mencampur daun yang telah halus yang dibagi menjadi enam sampel dengan berat masing-masing 1 gram. Kemudian larutan dicampurkan dengan aseton $80 \%$ dengan masing-masing perbandingan berat daun dengan banyaknya larutan aseton dalam milliliter yaitu 1:30, 1:25, 1:20, 1:15, 1:10, dan 1:5. Setelah di campur didiamkan selama 24 jam dan diekstrak dengan menggunakan Centrifuge.

2. Pengujian Absorbansi

Sampel yang telah dibuat kemudian dibagi menjadi lima sampel untuk masing-masing kosentrasi. Larutan kemudian dimasukkan ke dalam kuvet yang telah dibersihkan, kemudian dihitung nilai absorbansi tiap-tiap kosentrasi larutan pada panjang gelombang 400-700 nm, dengan setiap kosentrasi larutan dihitung sebanyak lima kali pengulangan.

3. Menghitung Jumlah Klorofil.

Untuk menghitung jumlah klorofil, larutan dengan perbandingan 1:10 $\quad(0,1$ $\mathrm{g} / \mathrm{ml}$ ) dimasukkan ke dalam spektrofotometri Uv-Vis dengan ketinggian $1 \mathrm{~cm}$ dihitung dari dasar kuvet dan dihitung Absorbansinya pada tiap panjang gelombanng yaitu pada panjang gelombang $663 \mathrm{~nm}$ dan $645 \mathrm{~nm}$. Untuk menghitung jumlah klorofil terlebih dahulu dilakukan kalibrasi dengan mengatur transmitan menjadi 100\% dengan mengatur pada aplikasi Uv-Win. Kalibrasi dilakukan pada sampel pelarut (aseton 80\%). Setelah nilai absorbansi didapatkan, nilai tersebut kemudian dihutung dengan menggunakan Persamaan berikut (Arnon ,1949)

Klo. $\mathrm{a}=12,7$ A-663 - 2,69 A-645 (mg/ 1)

Klo. $\mathrm{b}=22,9 A-645-4,68 A-663(\mathrm{mg} / \mathrm{l})$

Klo. Total $=20,2 A-645+8,02$ A-663 $(\mathrm{mg} / \mathrm{l})$

4. Pengukuran Konduktivitas

Pengukuran konduktivitas dilakukan dengan metode Two Point Probe dengan menglirkan arus pada larutan dengan menggunakan rangkaian dengan dua point. 


\section{HASIL DAN PEMBAHASAN}

1. Absorbansi

Pengujian nilai absorbansi dilakukan dengan menggunakan alat spektrofotomeri Uv-Vis. Data yang diambil berupa grafik nilai hasil absorbansi disetiap panjang gelombang mulai dari $400 \mathrm{~nm}$ sampai $700 \mathrm{~nm}$, dan diuji pada tiap-tiap kosentrasi larutan yaitu $0,03 \mathrm{~g} / \mathrm{ml}, 0,04 \mathrm{~g} / \mathrm{ml}, 0,05 \mathrm{~g} / \mathrm{ml}, 0,07$ $\mathrm{g} / \mathrm{ml}, 0,1 \mathrm{~g} / \mathrm{ml}$, dan $0,2 \mathrm{~g} / \mathrm{ml}$. Pada setiap kosentrasi dilakukan pengujian sebanyak 5 kali pengulangan. Gambar 1 hanya menampilkan spektrum pilihan untuk satu pengujian saja.

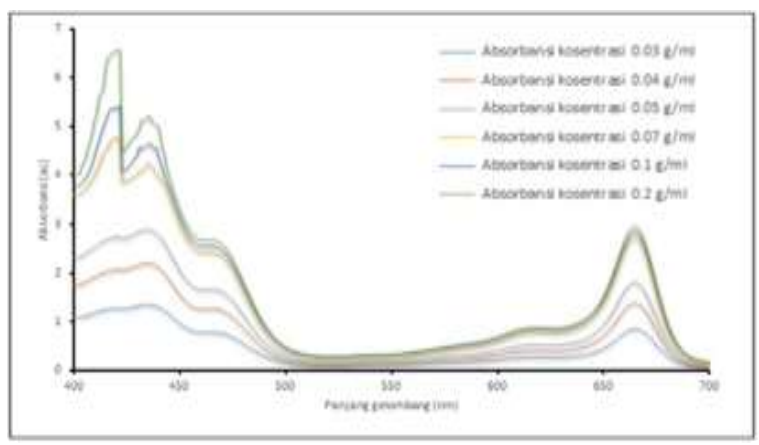

Gambar 1 Grafik absorbansi klorofil tiap kosentrasi larutan.

Grafik absorbansi seperti yang ditunjukkan pada Gambar 1 memperlihatkan bahwa larutan sampel merupakan larutan yang mengandung klorofil. Hal ini ditandai dengan adanya puncak-puncak absorbansi yang berada pada panjang gelombang tertertu. Puncak gelombang yang berada pada spektrum cahaya ungu-biru dan merah merupakan klorofil a, sedangkan puncak yang berada pada spektrum cahaya biru dan orange merupakan klorofil b. Dari puncak- puncak gelombang tersebut panjang gelombang di sekitar $665 \mathrm{~nm}$ dipilih untuk dianalisis. Hal ini dilakukan karena pada sekitar panjang gelombang $665 \mathrm{~nm}$ memiliki puncak absorbansi maksimum yang relatif stabil, sedangkan puncak absorbansi maksimum panjang gelombang 400-500 nm tidak konsisten. Dari hasil yang diperoleh dari 5 kali pengulangan, rata-rata absorbansi maksimum pada panjang gelombang 665 nm dapat dilihat pada Tabel 3.

Tabel 3 Peningkatan nilai absorbansi rata-rata terhadap kosentrasi pada panjang gelombang 665 nm.

\begin{tabular}{|c|c|c|c|c|c|c|c|}
\hline $\begin{array}{c}\text { Kosentrasi } \\
(\mathrm{g} / \mathrm{ml})\end{array}$ & $\begin{array}{c}\text { ahs 1 } \\
\text { (a.1L) }\end{array}$ & $\begin{array}{c}\text { abs2 } \\
\text { (a.u.) }\end{array}$ & $\begin{array}{c}\text { abs3 } \\
\text { (a.u.) }\end{array}$ & $\begin{array}{c}\text { abs4 } \\
\text { (a.u.) }\end{array}$ & $\begin{array}{c}\text { abs5 } \\
\text { (a.u.) }\end{array}$ & $\begin{array}{c}\text { rata- } \\
\text { rata } \\
\text { (a.u.) }\end{array}$ & STDEV \\
\hline 0,03 & 0,847 & 0,874 & 0,867 & 0,867 & 0,868 & 0,864 & 0,010 \\
\hline 0,04 & 1,449 & 1,383 & 1,339 & 1,374 & 1,396 & 1,388 & 0,039 \\
\hline 0,05 & 1,851 & 1,801 & 1,786 & 1,800 & 1,815 & 1,810 & 0,024 \\
\hline 0,07 & 2,733 & 2,733 & 2,733 & 2,733 & 2,734 & 2,733 & 0,000 \\
\hline 0,10 & 2,860 & 2,890 & 2,833 & 2,803 & 2,782 & 2,834 & 0,043 \\
\hline 0,20 & 2,905 & 2,955 & 2,964 & 2,965 & 2,968 & 2,951 & 0,026 \\
\hline
\end{tabular}

Grafik absorbansi seperti yang ditunjukkan pada Gambar 1 memperlihatkan bahwa larutan sampel merupakan larutan yang mengandung klorofil. Hal ini ditandai dengan adanya puncak-puncak absorbansi yang berada pada panjang gelombang tertertu. Puncak gelombang yang berada pada spektrum cahaya ungu-biru dan merah merupakan klorofil a, sedangkan puncak yang berada pada spektrum cahaya biru dan orange merupakan klorofil b. Dari puncakpuncak gelombang tersebut panjang 
gelombang di sekitar $665 \mathrm{~nm}$ dipilih untuk dianalisis. Hal ini dilakukan karena pada sekitar panjang gelombang $665 \mathrm{~nm}$ memiliki puncak absorbansi maksimum yang relatif stabil, sedangkan puncak absorbansi maksimum panjang gelombang 400-500 nm tidak konsisten. Dari hasil yang diperoleh dari 5 kali pengulangan, rata-rata absorbansi maksimum pada panjang gelombang $665 \mathrm{~nm}$ dapat dilihat pada Tabel 3.

Pada Tabel 3 nilai rata-rata absorbansi maksimum pada panjang gelombang $665 \mathrm{~nm}$ untuk kosentrasi 0,1 g/ml yaitu sebesar 2,834 a.u. Pada kosentrasi yang sama jika dibandingkan dengan klorofil Nannocloropsis Sp (2,5 a.u.) klorofil daun biduri memiliki absorbansi yang lebih tinggi. Hubungan antara nilai absorbansi panjang gelombang $665 \mathrm{~nm}$ terhadap kosentrasi larutan dapat dilihat pada Gambar 3.

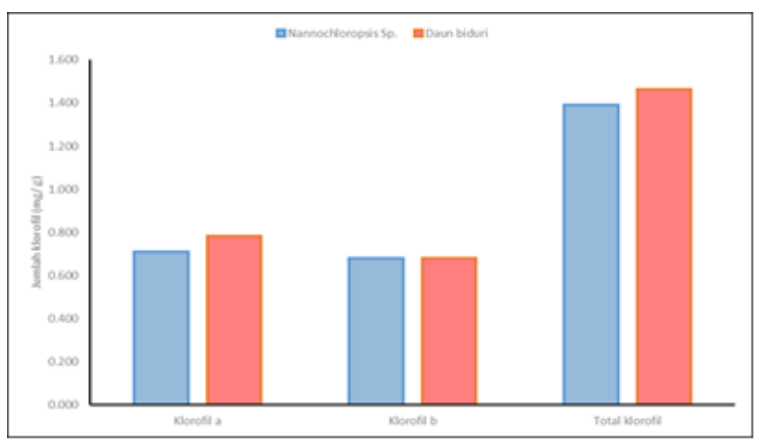

Gambar 3 Perbandingan jumlah klorofil biduri dan Nannochloropsis $S p$.

Error bars pada Gambar 3 dibuat berdasarkan nilai standar deviasi dari 5 kali data pengulangan untuk setiap kosentrasi. Nilai standar deviasi yang didapatkan terhitung kecil, menunjukkan bahwa tingkat keragaman data pengulangan yang sedikit dan menyatakan bahwa perngukuran dilakukan dengan akurasi yang cukup baik. Berdasarkan kurva pada Gambar 3 yang di bentuk dengan menggunakan Microsoft excel dapat diperoleh kosentrasi optimum untuk mendapatkan absorbansi maksimum. Kosentrasi optimum diperoleh jika difrensial dari persamaan kurva sama dengan nol. Dari hasil perhitungan diperoleh kosentrasi optimum adalah 0,15 $\mathrm{g} / \mathrm{ml}$.

\section{Jumlah Klorofil}

Perhitungan jumlah klorofil dilakukan dengan menggunakan metode Arnon (1949) seperti yang ditunjukkan pada Persamaan 6. Pengukuran dilakukan pada kosentrasi $0,1 \mathrm{~g} / \mathrm{ml}$. Data yang diambil dalam menghitung jumlah klorofil adalah nilai absorbansi dari dua panjang gelombang (645 nm dan $663 \mathrm{~nm}$ ). Nilai absorbansi dapat dilihat pada Gambar 2.

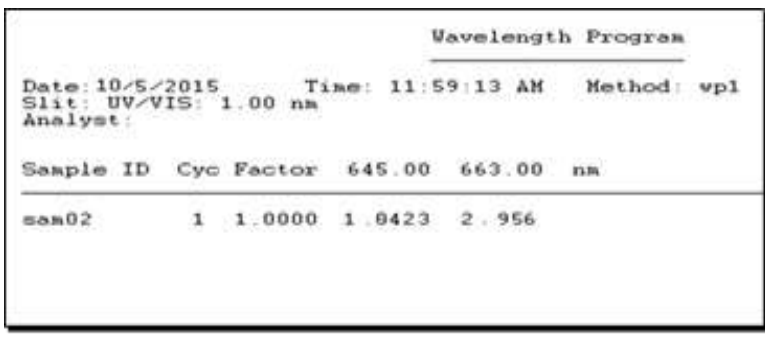

Gambar 2 Nilai absorbansi larutan pada panjang gelombang 645 dan $663 \mathrm{~nm}$.

Berdasarkan Gambar 2, jumlah klorofil dari daun biduri

\section{Potensi Daun Biduri (Calotropis gigantea) Sebagai Bahan Aktif Dye-Sensitized Solar Cell (DSSC)}


dapat dihitung

dengan

menggunakan metode arnon. Dalam

perhitungan tersebut satuan jumlah klorofil adalah milligram per 1 liter larutan (mg/l). Untuk mendapatkan kadar milligram klorofil per 1 gram daun, maka dilakukan konversi. Konversi dapat dilakukan jika volume hasil ekstraksi larutan klorofil diketahui. Dalam perhitungan ini (kosentrasi 0,1 $\mathrm{g} / \mathrm{ml}$ ), volume larutan hasil ektraksi 1 gram daun adalah $24 \mathrm{ml}$. Hasil perhitungan jumlah klorofil adalah sebagai berikut:

a. Klorofil $\mathrm{a}=(12,7 \times 2,956)-$ $(2,69 \times 1,842)$

$=32,585 \mathrm{mg} / \mathrm{L}$

$32,585 / 1000=x / 24$

$\mathrm{x}=(32,585 \times 24) / 1000=0,782$

Maka jumlah klorofil a dalam 1 g daun adalah 0,782 mg.

b. Klorofil $b=(22,9 \times 1,842)-(4,68$

$\mathrm{x} 2,956)$

$=28,355 \mathrm{mg} / \mathrm{L}$

$28,355 / 1000=\mathrm{x} / 24$

$\mathrm{x}=(28,355 \times 24) / 1000=0,681$

Maka jumlah klorofil b dalam $1 \mathrm{~g}$ daun adalah $0,681 \mathrm{mg}$.

c. Jumlah total $=(20,2 \times 2,956)+$ $(8,02 \times 1,842)$

$=60,921 \mathrm{mg} / \mathrm{L}$

$60,921 / 1000=x / 24$ $x=60,921 \times 25 / 1000=1,462$

Maka jumlah total klorofil dalam $1 \mathrm{~g}$ daun adalah 1,462 mg.

Pada hasil perhitungan menunjukkan bahwa kandungan klorofil dalam daun biduri lebih banyak mengandung klorofil a dibanding klorofil b. Jumlah klorofil a dalam daun adalah sebesar $0,7820 \mathrm{mg} / \mathrm{g}$, dan klorofil b sebesar $0,6805 \mathrm{mg} / \mathrm{g}$, dan total keseluruhan klorofil sebanyak $1,4621 \mathrm{mg} / \mathrm{g}$. Sedangkan jumlah klorofil Nannocloropsis $S p$, terhitung memiliki klorofil a sebesar $0,7101 \mathrm{mg} / \mathrm{g}$ dan klorofil b sebesar $0,6795 \mathrm{mg} / \mathrm{g}$ dan total klorofil sebanyak $1,3892 \mathrm{mg} / \mathrm{g}$. Hasil perbandingan antara jumlah klorofil biduri dan Nannochloropsis Sp. ditunjukkan pada gambar 4.

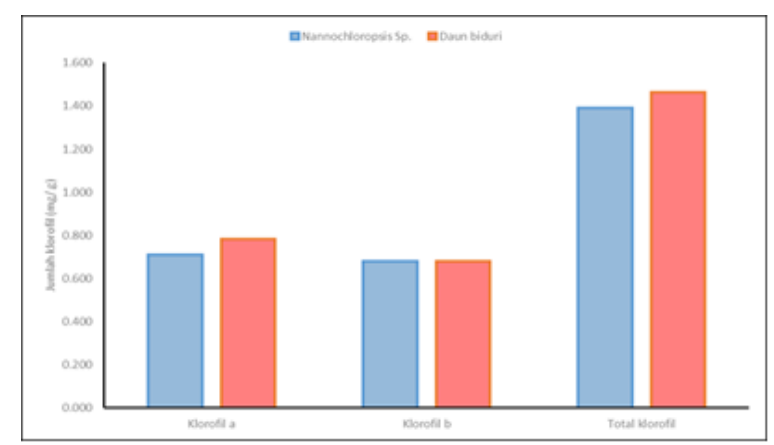

Gambar 4 Perbandingan jumlah klorofil biduri dan Nannochloropsis Sp.

Dari hasil perbandingan yang ditunjukkan pada Gambar 4 menunjukkan bahwa kadar klorofil daun biduri lebih tinggi dari Nannocloropsis Sp. Hasil ini sesuai dengan absorbansi yang lebih tinggi untuk kosentrasi yang sama $(0,1 \mathrm{~g} / \mathrm{ml})$. 
Oleh karena daun biduri memiliki kadar klorofil yang lebih tinggi maka daun biduri memiliki potensi untuk dijadikan sebagai bahan aktif DSSC.

\section{Data konduktivitas listrik.}

Pengambilan data-data untuk menghitung nilai konduktivitas listrik dilakukan dengan menggunakan metode two-point probe. Resistor (R) yang digunakan adalah $20 \Omega$, tegangan masukan (Vs) sebesar 5,4 Volt, luas penampang $A=1,33 \quad x \quad 10-5 \quad \mathrm{~m} 2$ dan panjang tabung $\mathrm{L}=11,3 \times 10^{2} \mathrm{~m}$. Data yang diambil dari pengukuran berupa nilai tegangan pada resistor untuk setiap kosentrasi berbeda yaitu $0,03 \mathrm{~g} / \mathrm{ml}, 0.04$ $\mathrm{g} / \mathrm{ml}, 0,05 \mathrm{~g} / \mathrm{ml}, 0,07 \mathrm{~g} / \mathrm{ml}, 0,1 \mathrm{~g} / \mathrm{ml}$, dan $0,2 \mathrm{~g} / \mathrm{ml}$. Tegangan pada resistor juga diukur ketika sampel hanya berupa aseton $80 \%$. Hasil pengukuran tegangan resistor (VR) ditunjukan pada Tabel 1 dan Tabel 2.

Tabel 1 Data hasil pengukuran nilai tegangan resistor untuk sampel aseton $80 \%$.

\begin{tabular}{|c|c|c|c|c|c|}
\hline \multirow{2}{*}{$\begin{array}{c}\text { Aseton } \\
805 \%\end{array}$} & \multicolumn{5}{|c|}{ VR $\left(\times 10^{-1}\right.$ Volt) } \\
\cline { 2 - 6 } & I & II & III & IV & V \\
\cline { 2 - 6 } & 0,226 & 0.228 & 0,228 & 0,227 & 0,230 \\
\hline
\end{tabular}

Tabel 2 Data hasil pengukuran nilai tegangan resistor larutan klorofil.

\begin{tabular}{|c|c|c|c|c|c|}
\hline \multirow{2}{*}{$\begin{array}{c}\text { Kosentrisi } \\
\text { (goimi) }\end{array}$} & \multicolumn{5}{|c|}{$V_{n}\left(x 10^{-3} V_{0}\right.$ in $)$} \\
\hline & 1 & II & III & IV & V \\
\hline 0,03 & 0.599 & 0.589 & 0.590 & 0.601 & 0,601 \\
\hline 0,04 & 0,712 & 0,709 & 0,717 & 0,712 & 0,722 \\
\hline 0,05 & 1.053 & 1,057 & 1,054 & 1.046 & 1.101 \\
\hline 0,07 & 1,290 & 1.297 & 1,210 & 1.294 & 1.294 \\
\hline 0,10 & 1,514 & 1.516 & 1,512 & 1.512 & 1.513 \\
\hline 0.20 & 1,902 & 1,900 & 1,902 & 1.890 & 1,901 \\
\hline
\end{tabular}

Berdasarkan Tabel 1 nilai konduktivitas dapat dihitung. Hasil perhitungan nilai konduktivitas dapat dilihat pada Tabel 4. Dari hasil perhitungan yang ditampilkan pada Tabel 4 maka didapatkan hubungan antara konduktivitas dan kosentrasi pada kondisi terang dan gelap ditunjukkan pada Gambar 5.

Tabel 4 Data hasil perhitungan konduktivitas klorofil daun biduri.

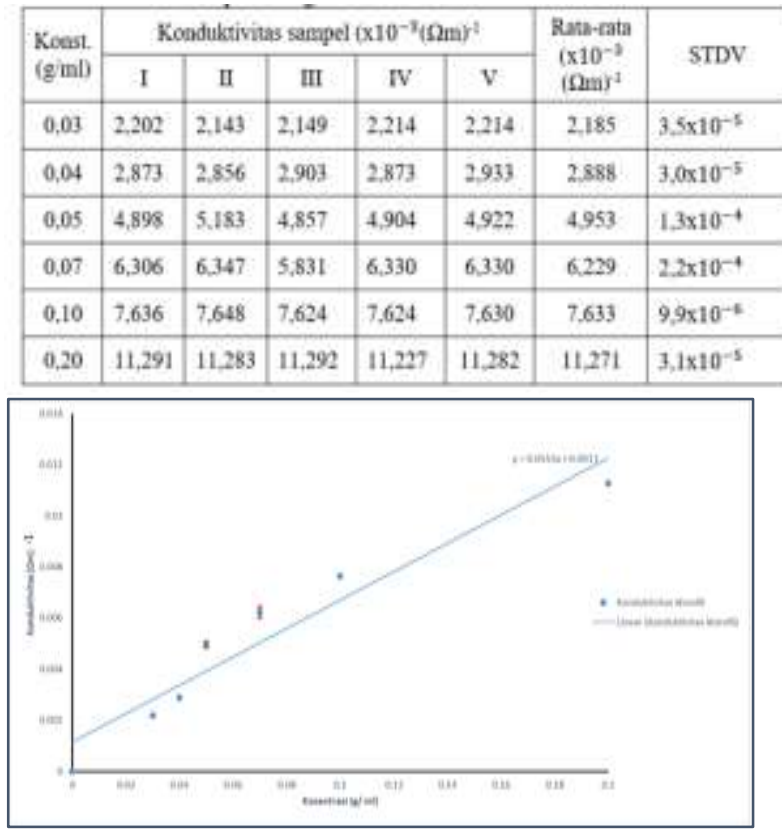

Gambar 5 Grafik nilai rata-rata konduktivitas klorofil biduri.

Error bars pada Gambar 5 dibuat berdasarkan nilai standar deviasi dari 5 data pengulangan pada setiap kosentrasi. Kemiringan garis lurus adalah 0,0555. Hal ini menunjukkan adanya kenaikan konduktivitas sebesar $0,0555 \quad(\Omega \mathrm{m})-1$ untuk setiap penambahan kosentrasi larutan sebesar $1 \mathrm{~g} / \mathrm{ml}$. Perbedaan kemiringan garis untuk absorbansi pada Gambar 3 dan kemiringan garis untuk konduktiitas pada Gambar 5 terjadi karena

\section{Potensi Daun Biduri (Calotropis gigantea) Sebagai Bahan Aktif Dye-Sensitized Solar Cell (DSSC)}

(Suprianto dkk) 
pengukuran absorbansi dilakukan dengan menggunakan cahaya. Hasil pengukuran absorbansi dipengaruhi oleh kosentrasi (tingkat kejenuhan) larutan, sedangkan pengukuran konduktivitas tidak dipengaruhi kosentrasi larutan. Berdasarkan konduktivitasnya maka klorofil daun biduri memiliki potensi untuk dijadikan bahan aktif DyeSensitized Sollar Cell (DSSC).

\section{UCAPAN TERIMA KASIH}

Ucapan kepada teman-teman, kepala laboratorium, dan laboran, yang sudah membantu dalam pengambilan data guna menyelesaikan tugas akhir ini.

\section{DAFTAR PUSTAKA}

Adisti. R.A, 2007, Fungsi Alat Tubuh Tumbuhan, Institut Pertanian Bogor, Bogor.

Ardianto, Wahyunanto Agung Nugroho, Sandra Malin Sutan, 2015, Uji Kinerja Dye Sensitized Solar Cell Menggunakan Lapisan Capacitive Touchscreen Sebagai Substrat dan Ekstrak Klorofil Nannochloropsis Sp. Sebagai Bahan Dye Sensitized dengan Variasi Ketebalan TiO2, Universitas Brawijaya, Malang.

Arnon , T., 1949. A method for the extraction of chlorophyll from leaf tissue without maceration. Can. J.

Bot. 57: 1332-1334.

Astuti dan 2010, Biodiesel
Mikroalga: Perbanyakan Biomassa melalui Penambahan Nutrisi Secara Bertahap, Jurnal ilmu hayati dan fisik Pusat Penelitian LIPI. Bandung.

Witono, Y., 2008, Deklorifilasi Ekstrak Protease Dari Tanaman Biduri Dengan Absorban Celite, Fakultas Teknologi Pertanian, Universitas Jember, Jember 